\title{
An Empirical Verification of Occupational Health Hazards on Sawmill Workers
}

\author{
*Yusuff, A.Q. \\ Adegbite, R. A. \\ Awotedu, O. L. \\ Akinosho, H. 0. \\ Federal College of Forestry, Ibadan, Oyo state, Nigeria. \\ *Corresponding Author Email: yusadeq@yahoo.com
}

Doi:10.5901/ajis.2014.v3n6p511

\begin{abstract}
The study investigates an empirical verification of occupational health hazards on sawmill workers at various sawmill within the Ibadan land local governments. The data were collected through the use of self-structured questionnaires majority closedended with few open-ended question was administered to 10 local government plank markets. Simple descriptive analysis such as respondents frequency and simple percentages were used to describe the socio-demographic characteristics of the respondents while regression analyses were employed to determine respondents health disorders experienced and other preventive measured by the sawmill worker. It was revealed that the average age for all respondents was 35 years, thus showing that majority of the respondent was in the middle age-categories. Result shown that $97.5 \%$ of the respondents are Male while the remaining 2.5\% are Female, indicating that, it is men's job.56.25\% had no formal education while $20 \%$, $13.75 \%$ $7.5 \%$ and $2.5 \%$ had spiritual, primary, secondary and tertiary education respectively. Three variables were significant in influencing the level of occupational health hazards and disorders of the respondents. These are respondents health disorders experienced $(p<0.01)$, years of experience $(p<0.05)$ and educational level $(p<0.1)$. The study discovered some health hazards and disorders associated with the sawmill work in Ibadan land. It was also discovered that wastes generated in the sawmill industries had a lot of effects on the health conditions of workers. The hazards and disorders need integrated approach in respect of prevention and control. Therefore, advices were given to the government, the factories and the communities in general.
\end{abstract}

Keywords: questionnaires, hazards, sawmill, ergonomics, regression analysis.

\section{Introduction}

It has been discovered for centuries that human occupation constitutes variety of hazards in one way or the other. Occupational health is essentially preventive medicine. For this reason, the joint International Labour Organisation I World Health Organisation (ILO/WHO) Committee on occupational health in the course of its session held in 1950 defined occupation health as aim to the promotion and maintenance of the highest degree of physical, mental and social wellbeing of the workers in all occupation, the prevention among workers of departures from health caused by their working conditions, the prevention of workers in their employment from risk resulting from factors adverse to health; the placing and maintenance of the workers adapted to his/her physiological and psychological requirement to sum up the adaptation of works to man and each man to his job. Occupational health is also the scientific study of interaction between man's occupation and his health.

Like any working environment, a sawmill is a facility where logs are cut into boards (timber). The basic operational mechanism is much like a hundred of years back; a log enters on one end dimensional lumber exits on the other end. Logging fells the trees, and log bucking cut them to length, logs are taken by trucks, trail or river to the sawmill. Logs are sealed either on the way to the mill or upon arrival at the mill. Debarking moves back from the logs. The head-saw (head rig) or primary saw, break the log into cunt (unfinished logs) and pitch with smooth edge. Depending upon the species and quality of the log, with cunt with either be further broken by a re-saw or gang edger into multiple pitches end/boards. Edging will take the fitch and trim off all irregular edges leaving four sides lumber to dry to remove moisture.

The idea developed from the water driven sawmill up to a modern reconstruction sawmill. Sawmill became widespread in medieval Europe in the year 1250AD and in Madeira 1420AD and widely in Europe in $16^{\text {th }}$ century. 
In addition, steam or petrol powered traction engines allowed the entire sawmill to be mobile. In the twenty century, the introduction of electricity and high technology furthered this process. Technology has changed sawmill operations significant in recent years, emphasising increasing profit through waste management and increase energy efficiency as well as improving operator safety.

In the past, it was customary to think of occupation health entirely in relation to factories and mines; hence the terms " industrial hygiene " or "industrial health "were in vogue. Modern concepts of occupational health now embrace all types of employment including mercantile and commercial enterprise, service trades, forestry and agriculture and include the subject of industrial hygiene, industrial disease, industrial accidents, toxicology in relation to industrial hazards, industrial rehabilitation and occupation psychology, occupational agriculture and ergonomics.

"The object of ergonomics is achieving the best through adjustment of man and his work, for the improvement of human deficiency and well being." The application of ergonomics has made a significant contribution to producing industrial accidents and to the overall health efficiency of the workers. The industrial revolution and the present capitalism, the desire to produce and sell products should not overshadow the freedom of safety and fundamental right to live and let live. The volume and physical properties of chemicals found in sawmill pose and wide range of health hazards, example is a wide range of adhesives and coating agent use in finishing wood product many are hazardous to the health of employees.

Similarly, poisonous plants as some trees pose poisonous substances in their roots e.g. position ivy, oak and sumac constitute health hazards. On the same vein, saw blades generate find dust containing cobalt in a silvery bluishwhite, odourless and magnetic metal. The fume and dust of cobalt metal without proper or adequate ventilation over exposure is possible. This is combustible and burns brilliantly in the air of room temperature. It may form explosive in the air. The sharpness and sharp pointed end of some tools constitute accidents possibilities and many other hazards.

\subsection{Classification of Occupational Health Hazards}

In any tropical sawmill, occupational health hazards can be classified into four broad groups. These are:

Physical: It means things that can be seen, heard or touched e.g. noise, temperature, pressure, vibration, radiation, dust, poisonous substances and the refuse waste.

Biological: For grouping of living organism e.g. bacteria, virus, fungi, algae, protozoa helmintistics agent, pest and the parasitic organism.

Psycho-social: It results from human mind and his social setup e.g. tension, stress, fatigue, lack of motivation and human relation, etc.

Ergonomics: Proper installation of machines, manpower development and right tool for the right worker approaches.

\section{Material and Methods}

\subsection{Study Area:}

The study was carry out among the workers at the various sawmill within the Ibadan land local governments. As the capital city of Oyo state, it consists of 11 local government areas namely: Ibadan South West, Ibadan North West, Ibadan North East, Ibadan South East, Ibadan North, Ido, Egbeda, Oluyole, Akinyele and Ona Ara while Lagelu were used to test the reliability of the research.

\subsection{Sampling procedure and sample size:}

A self-structured questionnaire majority closed ended with few open-ended question was administered. Simple random sampling technique was used to select sample respondents from these markets. A total of eight hundred (800) respondents were selected. Eighty (80) respondents from each local government plank market. This allows the study findings to be generalised to a larger population.

\section{Data Analysis}

Simple descriptive statistics such as frequency countable and percentages were used and inferential statistics of multiple 
regression analysis to test for the hypothesis at $1 \%, 5 \%$ and $10 \%$ level of significant.

\subsection{Multiple Regression Analysis}

The implicit form of the model is given by: $Y=f\left(X_{1}, X_{2}, X_{3}, X_{4}, X_{5}, X_{6}\right)$ where

$Y=$ Level of Occupational health hazards and disorders of the respondents

$X_{1}=$ Age of sawmill workers in years

$X_{2}=$ Sex of sawmill workers ( $O$ for male, 1 for female)

$X_{3}=$ Religion of the sawmill workers ( $O$ for Islam, 1 for Christianity, 2 for Traditional and 3 for others)

$X_{4}=$ Tribe of the sawmill workers ( $O$ for Yoruba, 1 for Igbo, 2 for Hausa and 3 for others)

$X_{5}=$ Qualification/Educational level of sawmill workers in years

$X_{6}=$ Year of experience

$\mathrm{X}_{7}=$ Respondents health disorders experienced

$X_{8}=$ Other preventive measures by the sawmill workers

Linear, Semi-log and double-log functions were tried out. The double - log function was found to have conformed to the a priori expectation, it was also the most appropriate in terms of both statistical and economic criteria. The explicit form of the three models is as follows:
Linear: $\quad Y=B_{0}+B_{1} X_{1}+B_{2} X_{2}+B_{3} X_{3}+\ldots+B_{8} X_{8}$
Semi-log: $\quad Y=B_{0}+B_{1} \ln X_{1}+B_{2} \ln X_{2}+B_{3} \ln X_{3}+\ldots+B_{8} \ln X_{8}+e$
Double-log: $\quad \ln Y=B_{0}+B_{1} \ln X_{1}+B_{2} \ln X_{2}+B_{3} \ln X_{3}+\ldots+B_{8} \ln X_{8}+e$

A priori (expectation)

All the variables except respondents health disorders experienced and other preventive measures by the sawmill workers are expected to carry a positive sign. Thus, as these variables increase, occupational health hazard and disorders would also increase. For the variables that are expected to carry a negative sign, an increase in these variables would result in a decrease in occupational health hazard and disorders.

\section{Results and Discussions}

\subsection{Socio-demographic characteristics of the respondents.}

Table 1 revealed that the respondents were in ages 15-20,21-25,26-30,31-35 and 36 \& above representing $12.5 \%, 13.75 \%, 16.25 \%, 25 \%$ and $32.5 \%$ respectively. Average age for all the respondents was 35 years, thus showing that majority of the respondents was in the middle age categories. Married respondents were $83.75 \%$ while the remaining $16.25 \%$ were single, divorced and separated. It also reveals that $97.5 \%$ of the respondents are male while the remaining $2.5 \%$ are female, thus showing that the job is specially meant for men. On educational status, $56.25 \%$ had no formal education while $20 \%, 13.75 \%, 7.5 \%$ and $2.5 \%$ representing religious/spiritual, primary, secondary and tertiary education respectively which indicates that majority of the respondents had no opportunity to obtain formal education. The table indicates that the respondents have a long exposure to sawmill hazards. On religion, $50 \%$ are Muslims, $37.5 \%$ are Christians, and $12.5 \%$ are traditional religion and others. Finally, it was revealed that $12.5 \%$ are for other tribes apart from Yoruba. This was as a result that the location is Yoruba land. 
Table 1: Socio-demographic characteristics of respondents.

\begin{tabular}{|c|c|c|}
\hline Socio-demographic & Frequency & Percentage \% \\
\hline Characteristics & & \\
\hline $\begin{array}{l}\text { AGE (YRS) } \\
15-20 \\
21-25 \\
26-30 \\
31-35 \\
36 \text { \& Above } \\
\text { Total }\end{array}$ & $\begin{array}{l}100 \\
110 \\
130 \\
200 \\
260 \\
\mathbf{8 0 0}\end{array}$ & $\begin{array}{l}12.5 \\
13.75 \\
16.25 \\
25 \\
32.5 \\
100\end{array}$ \\
\hline $\begin{array}{l}\text { SEX } \\
\text { Male } \\
\text { Female } \\
\text { Total }\end{array}$ & $\begin{array}{r}780 \\
20 \\
800\end{array}$ & $\begin{array}{c}97.5 \\
2.5 \\
100\end{array}$ \\
\hline $\begin{array}{l}\text { RELIGION } \\
\text { Islam } \\
\text { Christianity } \\
\text { Traditional } \\
\text { Others } \\
\text { Total }\end{array}$ & $\begin{array}{c}400 \\
300 \\
60 \\
40 \\
800\end{array}$ & $\begin{array}{l}50 \\
37.5 \\
7.5 \\
5 \\
100\end{array}$ \\
\hline $\begin{array}{l}\text { TRIBE } \\
\text { Yoruba } \\
\text { Igbo } \\
\text { Hausa } \\
\text { Others } \\
\text { Total }\end{array}$ & $\begin{array}{c}700 \\
50 \\
30 \\
20 \\
\mathbf{8 0 0}\end{array}$ & $\begin{array}{l}87.5 \\
6.25 \\
3.75 \\
2.5 \\
100\end{array}$ \\
\hline $\begin{array}{l}\text { QUALIFICATION } \\
\text { Non-Formal } \\
\text { Spiritual or Religious } \\
\text { Primary } \\
\text { Secondary } \\
\text { Tertiary } \\
\text { Total }\end{array}$ & $\begin{array}{r}450 \\
160 \\
110 \\
60 \\
20 \\
800\end{array}$ & $\begin{array}{l}56.25 \\
20 \\
13.75 \\
7.5 \\
2.5 \\
100\end{array}$ \\
\hline $\begin{array}{l}\text { EXPERIENCE (YRS) } \\
5-10 \\
10-15 \\
15-20 \\
\text { Above } 20 \text { years } \\
\text { Total }\end{array}$ & $\begin{array}{r}380 \\
290 \\
100 \\
30 \\
800\end{array}$ & $\begin{array}{l}47.5 \\
36.25 \\
12.5 \\
3.75 \\
100\end{array}$ \\
\hline $\begin{array}{l}\text { MARITAL STATUS } \\
\text { Single } \\
\text { Married } \\
\text { Divorced } \\
\text { Separated } \\
\text { Total }\end{array}$ & $\begin{array}{l}90 \\
670 \\
20 \\
20 \\
\mathbf{8 0 0}\end{array}$ & $\begin{array}{l}11.25 \\
83.75 \\
2.5 \\
2.5 \\
100\end{array}$ \\
\hline
\end{tabular}

Table 2a tries to relate the variables with the research question. On the investigation whether there is any relationship between work and health, $92.5 \%$ respondents agreed. On the type of health hazards associated with the sawmill business, $82.5 \%$ accepted that the hazards is physical while $7.5 \%$, and $2.5 \%$ accepted it was biological and social hazards respectively. The remaining $7.5 \%$ did not agree that these hazards are co-ordinated to their working environment. To identify the working condition with health related hazards, 37.5\% agreed, $7.5 \%$ did not agree and $55 \%$ were undesired. The investigation of the nature and characteristics of health hazards, $37.5 \%$ related their work with variety of diseases, $25 \%$ contagious, $7.5 \%$ allergic, $5 \%$ vector bone diseases while $62.5 \%$ were unknown.

To dig down the roots of conditions experience during years of service in the sawmill and subsequently, the summary results is given on health condition (Table $2 \mathrm{~b}$ ). Therefore, $37.5 \%$ had positive answer while $62.5 \%$ had answered negatively on their experience with some health disorders in their course of duties. Also, $21.25 \%$ agreed that the disorders were regular while $16.25 \%$ agreed that their experience with health hazards was occasional.

Table 2a: Health hazards and disorders

\begin{tabular}{|lllll|}
\hline S/N & Variables & & Respondents & Percentage \\
1. & Do you think your work has health related hazards & Yes & 740 & 92.5 \\
& & No & 60 & 7.5 \\
& & Total & 800 & 100 \\
2. & If yes, what type of health hazards mention? & Physical & 660 & 82.5 \\
& & Biological & 60 & 7.5 \\
& & Social & 20 & 2.5 \\
& & Unknown & 60 & 7.5 \\
3. & Do you think this work has health related hazards? & Total & 800 & 100 \\
& & Yes & 300 & 37.5 \\
& & No & 60 & 7.5 \\
& & Unknown & 440 & 55 \\
& & Total & 800 & 100 \\
\hline
\end{tabular}




\begin{tabular}{|llll|}
\hline 4. If yes, what type of health hazards? & Contagious & 200 & 25 \\
& Allergic & 60 & 7.5 \\
& Vector borne & 40 & 5 \\
& Unknown & 500 & 62.5 \\
& Total & 800 & 100 \\
\hline
\end{tabular}

Table 2b:

\begin{tabular}{|c|c|c|c|c|c|}
\hline $\mathrm{S} / \mathrm{N}$ & Health condition & Yes & No & Regularly & Occasional \\
\hline a. & Accidents/cuts & 20 & 40 & & \\
\hline b. & Falls & & 20 & & \\
\hline c. & Irritation/disorder of the eye & 80 & 30 & $\sqrt{ }$ & \\
\hline d. & Nose and throat infection & 90 & & $\sqrt{ }$ & \\
\hline e. & Tiredness and headache & & 60 & & $\sqrt{ }$ \\
\hline f. & Skin disorder & 30 & 40 & & $\sqrt{ }$ \\
\hline g. & Heart problems & & 70 & & \\
\hline h. & Impaired hearing & & 20 & & \\
\hline i. & Deafness & & 100 & & \\
\hline j. & White fingers and numbness & & & & \\
\hline k. & Asthma & 40 & 60 & & $\sqrt{ }$ \\
\hline I. & Sleeplessness & & 20 & & \\
\hline \multirow[t]{2}{*}{$\mathrm{m}$. } & Any other illness & 40 & 40 & & $\sqrt{ }$ \\
\hline & Total & 300 & 500 & 2 & 5 \\
\hline
\end{tabular}

\begin{tabular}{|l|c|c|c|}
\hline Question & Variable & Respondents & Percentage \\
\hline \multirow{2}{*}{ Do you think these conditions (Health) are cause by or related to your work? } & Yes & 300 & 37.5 \\
& No & 500 & 62.5 \\
\hline Total & & $\mathbf{8 0 0}$ & 100 \\
\hline
\end{tabular}

On the preventive measures taken either by the government or the factory owner, it has been discovered that the measures taken are not adequate to safeguard the workforce to optimum health as presented in table 3 and table 4 .

Table 3: Accident prevention equipment available

\begin{tabular}{|llccccccc|}
\hline S/N & Equipment & Yes & No & Unknown & Regular & \multicolumn{3}{c|}{ Percentage } \\
& & & & & & Yes & No & Unknown \\
1. & Face mask & 20 & 30 & 750 & & 2.5 & 3.75 & 93.75 \\
2. & Eye shield & - & - & - & & & & - \\
3. & Hand gloves & - & 50 & 750 & & & 6.25 & 93.75 \\
4. & Protective garments & 150 & 200 & 450 & $\sqrt{ }$ & 18.75 & 25 & 56.25 \\
5. & Booth \& foot wears & 40 & 10 & 750 & $\sqrt{ }$ & 5 & 1.25 & 93.75 \\
& Total & $\mathbf{2 1 0}$ & $\mathbf{2 9 0}$ & & & $\mathbf{2 6 . 2 5}$ & $\mathbf{3 6 . 2 5}$ & \\
\hline
\end{tabular}

Table 4: Government effort towards accident prevention on sawmill working environment

\begin{tabular}{|lllll|}
\hline S/N & Variables & & Respondents & Percentage \\
1. & Has the government ever given any & Yes & 200 & 25 \\
& equipment/services to prevent accidents in your & No & 300 & 37.5 \\
& workplace? & I don't know & 300 & 37.5 \\
& & Total & 800 & 100 \\
2. & If yes, mention? & Equipments & 2.5 & 20.5 \\
& & Health education & 160 & 2.5 \\
& & Work shop & 20 & 7.5 \\
& & Unspecified & 600 & 100 \\
3. & Total & 800 & 16.25 \\
& As any Non-governmental organisation provided & Equipments & 0 & 40 \\
& any equipments/services to prevent accidents in & Health education & 130 & 43.75 \\
& this workplace? & Workshop & 320 & 100 \\
& & Unspecified & 350 & 0 \\
\hline
\end{tabular}




\begin{tabular}{|llll|}
\hline available to workers in this place provided by the & No & 300 & 37.5 \\
workers union? & I don't know & 500 & 62.5 \\
& Total & 800 & 100 \\
5. What measures are used to take care of & a. Visit health centre & 160 & 20 \\
accidents and health problems among workers? & b. Visit government hospital & 260 & 32.5 \\
& c. Visit private hospital & 160 & 20 \\
& d. Traditional probationers & 120 & 15 \\
& e. Medicine vendors & 10 & 1.25 \\
& f. Nothing done & 0 & 11.25 \\
& g. Other specify & 90 & 100 \\
\hline
\end{tabular}

\subsection{Regression Analysis}

The result of the regression analysis is presented in Table 5. From the table Age, Marital status, Educational level/Qualification and Years of experience were positively related to the Level of occupational health hazards and disorders. Other variables that carried the expected positive sign include Sex and Tribes. The positive relationship of Sex to Level of occupational health hazards and disorders shows that Male sawmill workers are more prone to the risk than their Female counterparts. In the same vein, more Muslim participated than any other religion. It was also discovered that the higher the size of Yoruba, the higher the level of occupational health hazards and disorders to them. This is expected given the fact that the decrease the people's participation in sawmill activities. Thus, the negative sign carried by these variables (Respondents health disorders experienced and other preventive measures) shows that the higher the Respondents health order experienced and other preventive measures, the lower the Level of occupational health hazards and disorders of the sawmill workers.

Three variables were, however, significant in influencing the level of occupational health hazards and disorders of the respondents. These are respondents health disorders experienced $(p<0.01)$, years of experience $(p<0.05)$ and educational level $(p<0.1)$. The $R^{2}$ value of $97.5 \%$ was high suggesting that the variation in the dependent variable is well explained by the independent variables. Also, F-value of 47.49 at $p<0.01$ showed that the model has a good fit.

Table 5: Result of Regression Analyses.

\begin{tabular}{|lcccl|}
\hline Variable & Co-efficient & Standard error & t-values & Level of Significance \\
Constant & 0.3875 & 0.1410 & 2.748 & $0.0024^{\star \star \star}$ \\
Age & 0.9321 & 0.8584 & 1.086 & 0.2109 \\
Sex & 0.7442 & 0.6124 & 1.2152 & 0.602 \\
Religion & 0.1289 & 0.0588 & 2.1922 & 0.212 \\
Tribe & 0.1125 & 0.2203 & 0.5107 & 0.629 \\
Qualification & 0.1582 & 0.0812 & 1.9483 & $0.095^{\star}$ \\
Experience (Years) & 0.7552 & 0.3041 & 2.4834 & $0.024^{\star \star}$ \\
Respondents health disorders experienced & -0.8447 & 0.2002 & -4.2193 & $0.000^{\star * \star}$ \\
Other preventive measures by the sawmill worker & -0.4868 & 0.1706 & -2.8535 & $0.0019^{\star \star \star}$ \\
\hline
\end{tabular}

$\mathrm{R}^{2}=97.5, \mathrm{~F}=47.49$ at $\mathrm{p}<0.01$.

***Significant at $1 \%$, **Significant at $5 \%$, *Significant at $10 \%$.

\section{Conclusion and Recommendation}

It was discovered that there are some health hazards and disorders associated with the sawmill work in Ibadan land. Since, sawmill by nature generate a lot of wastes, sawdust, wood off cuts, wood backs, plain shaving, wood reject, etc. with poor management, these waste poses great danger to the workforce and their immediate environment. Waste generation is concomitant aspect of living; it cannot vanish but can only be managed (Oluwagbemi 2010).

In view of the above, the hazards and disorders need integrated approach in respect of prevention and control. It was also discovered that waste generated in the sawmill industries had a lot of effects on the health conditions of workers and therefore the following recommendations are made:

Government

- They should make laws and enforce the laws so that health hazards are controlled in sawmill factories

- They should make regular environmental assessment which should be carried out in such industries and the 
newly proposed sites before commencing commercial activities.

- They should assign one agency to be responsible for sawmill inspection and laid down regulation.

- They should intensify the training of environmental health worker to monitor such factories accordingly

- They should mandate factories to make use of modern protective clothes and other gadgets in sawmill factories

Factories

- They should reduce at source waste generation to reduce the danger of waste improper disposal.

- They should employ ergonomics on proper placement of workers.

- They should employ modern incineration or readable method of waste disposal.

- They should regularly maintain their tools to avoid accidents during working time.

- They should be relocated far away from residential areas.

Community

- Community members should be warned not to be building houses near such factories

- The community should form health based team which will wash all pollutants

- Community member should inform the government about any suspected activities within their vicinity.

\section{Acknowledgement}

Mr. Bello Ibraheem; former student of the Department of Environmental Health Officers Tutors' course of the Federal Training Centre for Teachers of Health Sciences, University College Hospital, Ibadan, Nigeria; is hereby acknowledged.

\section{References}

Adetokunbo, O. et al (2003). Short Textbook of Public Health Medicine for the Tropics. U.K. London: Hodder Education.

Aibor, M. S.and Olorunda, J.O. (2006). Technical Handbook of Environmental Health in the 21 $1^{\text {st }}$ Century for Professionals and Students. Akure: Mercy Publishers.

Akpa, G. O.and Udoh, S.U. (2002). Environment Education for Sustainable Development, Focus on Nigeria. Jos: Fab Anach Nig. Ltd.

FRIN (2009). Journal of Forestry Research and Management, Forestry Research Institute Of Nigeria, Jericho hill, Ibadan: Volume 6 : pp1-9.

Jain, R. K. and Rao Sunil, S. (2009). Industrial Safety Health and Environmental Management Systems. India: Khanna Publishers.

Kleinbaun, D.G. and Kupper, L. L. (1978). Applied regression analysis and other multivariate methods. Boston: Duxbury.

Munro, B. H. and Page, E.B. (1993). Statistical Methods for Health Care Research. J.B. Hippincott Company. Philadelphia: $2^{\text {nd }}$ ed., 403pp.

Oluwagbemi, B.F. (2003). Themes and Issues in Occupational Health and Safety. Ibadan: Hure Prints (Printers and Publishers).

Oluwagbemi, B.F. (2010). Basic Occupational Health and Safety. Ibadan: Vertext Media Ltd.

Osanyingbemi, B.F. (1987). Basic Occupational Health. Ibadan: Educational Services Limited.

Park K. (2009). Textbook of Preventive Medicine. India: Prem Nagar, Jabalpur, Banarsidas Publishers.

Unuraye, L.O. and Olojoba, A.O. (2005). Occupational Safety and Environmental Helath Management . Second Edition. Ughelli: Aina Ohoror Printing Press Coy. 